\title{
The Human Polyomavirus, JCV, \\ Uses Serotonin Receptors to Infect Cells
}

Gwendolyn F. Elphick, ${ }^{1}$ William Querbes, ${ }^{1,2}$ Joslynn A. Jordan, ${ }^{1,2}$ Gretchen V. Gee, ${ }^{1,3}$ Sylvia Eash,, Kate Manley, 1,3 Aisling Dugan, 1,2 Megan Stanifer, ${ }^{1,3}$ Anushree Bhatnagar, ${ }^{4}$ Wesley K. Kroeze, ${ }^{4}$ Bryan L. Roth, ${ }^{4}$ Walter J. Atwood ${ }^{1,2,3 *}$

The human polyomavirus, JCV, causes the fatal demyelinating disease progressive multifocal leukoencephalopathy in immunocompromised patients. We found that the serotonergic receptor $5 \mathrm{HT}_{2 \mathrm{~A}} \mathrm{R}$ could act as the cellular receptor for JCV on human glial cells. The $5 \mathrm{HT}_{2 \mathrm{~A}}$ receptor antagonists inhibited JCV infection, and monoclonal antibodies directed at $5 \mathrm{HT}_{2 \mathrm{~A}}$ receptors blocked infection of glial cells by JCV, but not by SV40. Transfection of $5 \mathrm{HT}_{2 \mathrm{~A}}$ receptor-negative HeLa cells with a $5 \mathrm{HT}_{2 \mathrm{~A}}$ receptor rescued virus infection, and this infection was blocked by antibody to the $5 \mathrm{HT}_{2 \mathrm{~A}}$ receptor. A tagged $5 \mathrm{HT}_{2 \mathrm{~A}}$ receptor colocalized with labeled JCV in an endosomal compartment following internalization. Serotonin receptor antagonists may thus be useful in the treatment of progressive multifocal leukoencephalopathy.

The incidence of progressive multifocal leukoencephalopathy (PML) has increased 50-fold since 1979 and now affects nearly 1 in every 200,000 persons (1). The disease is due to infection of oligodendrocytes by the common human polyomavirus, JCV (2). Initial infection with JCV occurs early in childhood and eventually reaches a seroprevalence of

${ }^{1}$ Department of Molecular Microbiology and Immunology, ${ }^{2}$ Graduate Program in Pathobiology, ${ }^{3}$ Graduate Program in Molecular Biology, Cellular Biology, and Biochemistry, Brown University, Providence, RI 02912, USA. ${ }^{4}$ Department of Biochemistry, Case Western Reserve University Medical School, Cleveland, Ohio 44106, USA.

*To whom correspondence should be addressed. E-mail: Walter_Atwood@Brown.edu between 70 and $80 \%$ in the adult population. The initial infection is subclinical, and the virus establishes a lifelong persistent infection. At any given time, $\sim 5 \%$ of the population is actively excreting virus in the urine, and JCV is a frequent contaminant of untreated human sewage (3). PML occurs almost exclusively in severely immunosuppressed patients. The majority of cases occur in patients with AIDS, and to date there is no effective treatment (4). PML is initiated when JCV traffics from peripheral sites, such as the kidney and lymphoid organs, to the central nervous system (CNS) by unknown mechanisms. There is a strong association between JCV and human B lymphocytes, and the virus may traffic to the CNS in an 
infected B cell (5-7). Once in the CNS, JCV infects both oligodendrocytes and astrocytes.

$\mathrm{N}$-linked glycoproteins containing terminal alpha 2-6-linked sialic acid are a critical component of the JCV receptor (8). The tissue distribution of this receptor-type sialic acid strongly correlates with the known tropism of JCV for oligodendrocytes, astrocytes, B-lymphocytes, and kidney epithelial cells (9). JCV receptor interactions play a critical role in tropism, because a hybrid SV40 virus containing JCV capsid proteins maintains the restricted host range of JCV (10). Also, unlike the related polyomavirus SV40, which enters cells by caveolae-dependent endocytosis, JCV enters cells by a ligandinducible clathrin-dependent pathway (11-15).

Chlorpromazine, which blocks clathrindependent endocytosis, and the related compound clozapine effectively block JCV infection of glial cells (16). Both chlorpromazine and clozapine belong to a class of drugs known as serotonin-dopamine inhibitors (SDIs). Because glial cells express receptors for both dopamine and serotonin (Fig. 1A), we hypothesized that JCV may use either serotonin receptors or dopamine receptors to infect glial cells. To test this hypothesis, glial cells were treated with increasing concentrations of the dopamine antagonists bromocriptine and minaprine, and a dopamine agonist, pergolide. These agents have generally minimal activity against serotonin receptors $(17,18)$. Glial cells were also treated with increasing concentrations of antagonists with activity against both dopamine and serotonin receptors $(19,20)$. These included metoclopramide, chlorpromazine, and clozapine. The cells were then incubated with JCV at a multiplicity of infection (MOI) of 1.0 in the continued presence of drug. At 72 hours after infection, the cells were assayed for viral infection. The dopamine-specific antagonists, bromocriptine and minaprine, and the dopamine agonist, pergolide, had little to no effect on the infectivity of glial cells by JCV (Fig. 1B). In contrast, metoclopramide, chlorpromazine, and clozapine, which antagonize the 5HT2 serotonergic receptors, all significantly inhibited infection (Fig. 1B). Because these reagents are not highly specific, we next asked whether $5 \mathrm{HT}$ itself or selective 5HT2 receptor antagonists could inhibit JCV infection. Glial cells were treated in triplicate with increasing concentrations of 5HT (which down-regulates serotonin receptors), MDL100.907 (which selectively inhibits $5 \mathrm{HT}_{2 \mathrm{~A}} \mathrm{R}$ ), SB206553 (which inhibits $5 \mathrm{HT}_{2 \mathrm{C}} \mathrm{R}$ ), ketanserin (which inhibits $5 \mathrm{HT}_{2 \mathrm{~A}} \mathrm{R}$ and $5 \mathrm{HT}_{2 \mathrm{C}} \mathrm{R}$ ), or ritanserin (which inhibits $5 \mathrm{HT}_{2 \mathrm{~A}} \mathrm{R}, 5 \mathrm{HT}_{2 \mathrm{~B}} \mathrm{R}$, and $\left.5 \mathrm{HT}_{2 \mathrm{C}} \mathrm{R}\right)$ (21-25). 5HT and MDL100.907 both inhibited infection of glial cells by JCV at concentrations of $1.0 \mu \mathrm{M}$ (Fig. 1B). The $5 \mathrm{HT}_{2 \mathrm{C}}$ inhibitor SB206553 only slightly inhibited infection when used at $1.0 \mu \mathrm{M}$ (Fig. 1B).
The $5 \mathrm{HT}_{2 \mathrm{~A}}$ and $5 \mathrm{HT}_{2 \mathrm{C}}$ inhibitor ketanserin inhibited infection at $0.1 \mu \mathrm{M}$, and ritanserin also inhibited at $0.1 \mu \mathrm{M}$ (Fig. 1B).

A

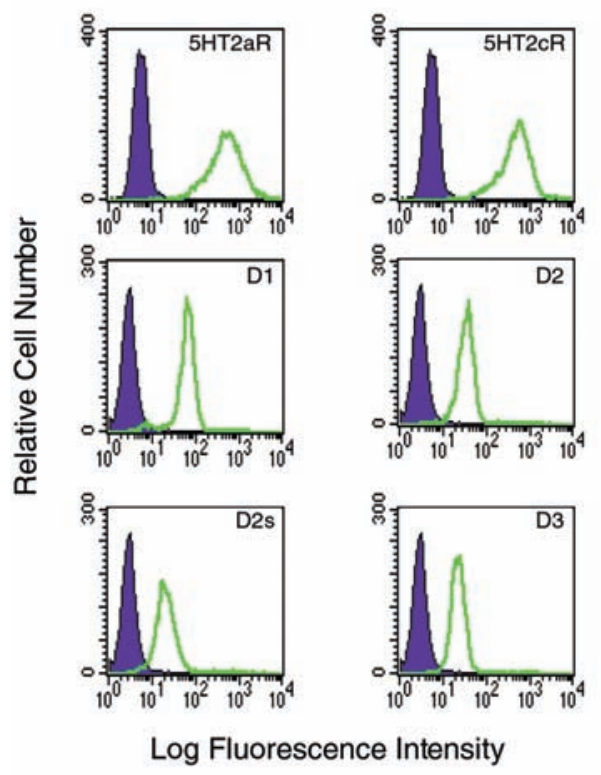

We next asked whether antibodies directed at $5 \mathrm{HT}_{2 \mathrm{~A}} \mathrm{R}, 5 \mathrm{HT}_{2 \mathrm{C}} \mathrm{R}$, or at the D1, D2, and $\mathrm{D} 3$ dopamine receptors could block in-

Fig. 1. (A) Glial cells express receptors for both serotonin and dopamine. Glial cells were incubated with irrelevant antibody (solid histograms), with monoclonal antibodies to the $5 \mathrm{HT}_{2 \mathrm{~A}}$ and $5 \mathrm{HT}_{2 \mathrm{C}}$ serotonergic receptors (top panels, open histograms), or with polyoclonal antibodies to the D1, D2, D2s, and D3 dopamine receptors (middle and bottom panels, open histograms). Antibody binding was detected with either goat anti-mouse or goat anti-rabbit secondary antibodies conjugated to AlexaFluor-488. (B) SDIs inhibited infection of glial cells by JCV. Glial cells were incubated with the dopamine antagonists bromocriptine and minaprine, a dopamine agonist, pergolide, or with metoclopramide, chlorpromazine, or clozapine, which antagonize both dopamine receptors and serotonin receptors. Cells were then challenged with JCV and infection scored at 72 hours after infection by indirect immunofluorescence assay of $\mathrm{V}$ antigen-expressing cells. The percentage of infected cells in untreated cultures was set at $100 \%$. The ability of these agents to inhibit JCV infection correlate with their ability to antagonize $5 \mathrm{HT}_{2 \mathrm{~A}}$ and $5 \mathrm{HT}_{2 \mathrm{c}}$ serotonin receptors. (Bottom panel) $5 \mathrm{HT}$ and specific 5HT2 antagonists inhibited infection of glial cells by JCV. Glial cells were incubated with 5HT, MDL100.907, SB206553, ketanserin, or ritanserin. Cells were challenged and scored for viral infection as described above. 5HT, MDL100.907, ketanserin, and ritanserin all significantly inhibited infection. SB206553 had a modest inhibitory effect on JCV infection.

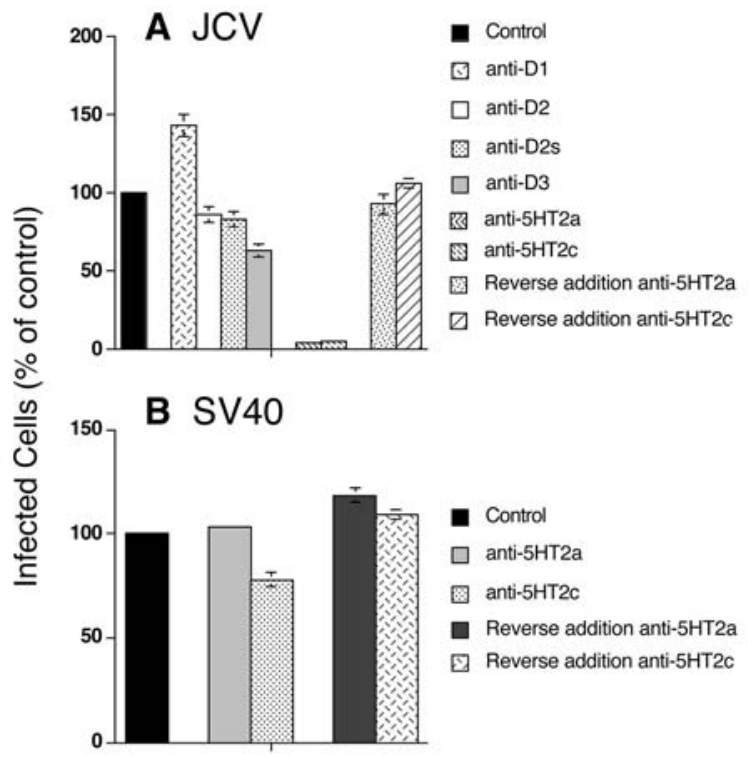

Fig. 2. (A) Antibodies directed at $5 \mathrm{HT}_{2 \mathrm{~A}} \mathrm{R}$ or $5 \mathrm{HT}_{2 \mathrm{C}} \mathrm{R}$, but not antibodies directed at dopamine receptors, inhibit JCV infection of glial cells. Glial cells were incubated with antibodies against either serotonin receptors or dopamine receptors as indicated. The cells were then challenged with JCV and infection scored at 72 hours after infection by indirect immunofluorescence analysis of $\mathrm{V}$ antigen-expressing cells. The percentage of infected cells in untreated cultures was set at $100 \%$. If antibodies to $5 \mathrm{HT}_{2 \mathrm{~A}} \mathrm{R}$ or $5 \mathrm{HT}_{2 \mathrm{C}} \mathrm{R}$ were added at 24 hours after infection, they had no effect on virus infection. (B) Antibodies directed at $5 \mathrm{HT}_{2 \mathrm{~A}} \mathrm{R}$ or $5 \mathrm{HT}_{2 \mathrm{C}} \mathrm{R}$ do not inhibit infection of glial cells by SV40, as indicated. 
Fig. 3. (A) HeLa cells express dopamine receptors but do not express $5 \mathrm{HT}_{2 \mathrm{~A}}$ or $5 \mathrm{HT}_{2 \mathrm{c}}$ serotonergic receptors. HeLa cells were incubated with irrelevant antibody (solid histograms), with monoclonal antibodies to the $5 \mathrm{HT}_{2 \mathrm{~A}} \mathrm{R}$ and $5 \mathrm{HT}_{2 \mathrm{C}} \mathrm{R}$ (top panels, open histograms), or with polyclonal antibodies to the D1, D2, D2s, and D3 dopamine receptors (middle and bottom panels, open histograms). Antibody binding was detected with either goat anti-mouse or goat anti-rabbit secondary antibodies conjugated to AlexaFluor-488. (B) Transient transfection of HeLa cells with the $5 \mathrm{HT}_{2 \mathrm{~A}}$ receptor rescues virus infection. HeLa cells were untreated, transfected with irrelevant plasmid DNA (mock), or with a $5 \mathrm{HT}_{2 \mathrm{~A}}$ receptor-expressing plasmid. At 24 hours after transfection, the cells were challenged with JCV and infection scored 48 hours later by indirect immunofluorescent analysis of T antigenexpressing cells. The cells were counterstained with Evans blue, which fluoresces red in the ultraviolet channel. T antigenexpressing cells could only be detected in HeLa cells transfected with the $5 \mathrm{HT}_{2 \mathrm{~A}}$ receptor clone. The percentage of ${ }^{2 \mathrm{~A}}$ antigen-positive cells is indicated in parentheses. (C) Stable transfection of HeLa cells with the $5 \mathrm{HT}_{2 \mathrm{~A}}$ receptor rescues virus infection. (Top panel) Analysis of $5 \mathrm{HT}_{2 \mathrm{~A}} \mathrm{R}$ expression on HeLa cells stably expressing $5 \mathrm{HT}_{2 \mathrm{~A}} \mathrm{R}$ (HeLa-5HT ${ }_{2 \mathrm{~A}} \mathrm{R}$ ). (Middle panel) HeLa- $5 \mathrm{HT}_{2 \mathrm{~A}} \mathrm{R}$ cells infected with JCV and stained for $\mathrm{T}$ antigen. The percentage of infected cells is indicated in parentheses. (Bottom panel)

\section{B HeLa Transient Tx C HeLa-5HT2aR}
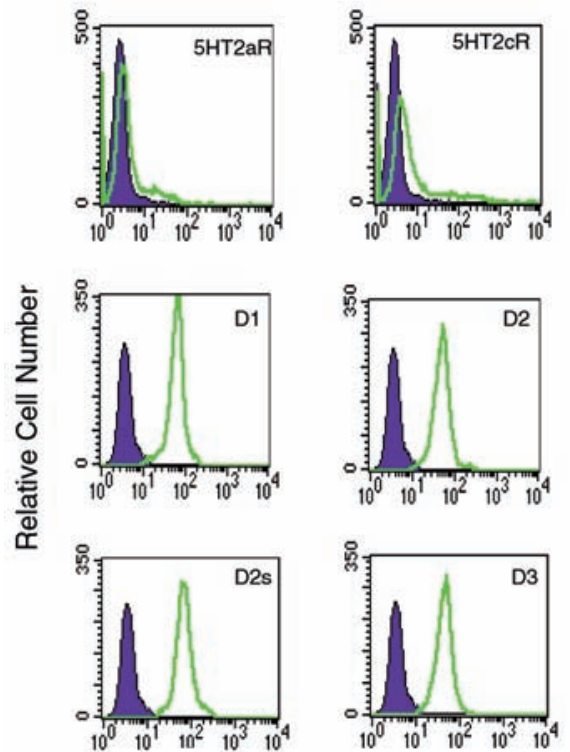

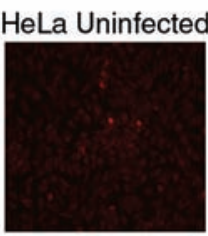

HeLa Mock

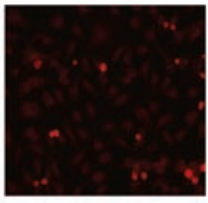

$5 \mathrm{HT} 2 \mathrm{aR}$

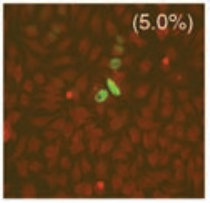

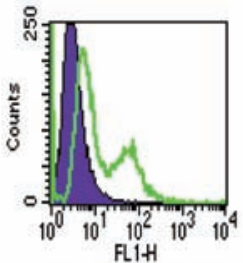
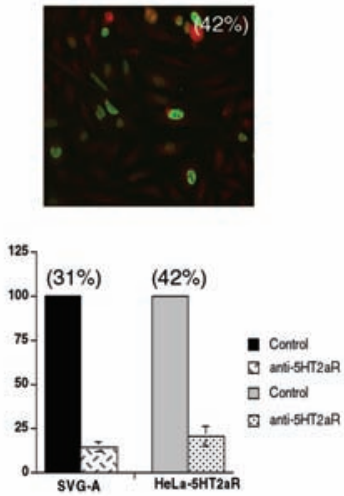

Fig. 4. Colocalization of JCV and $5 \mathrm{HT}_{2 \mathrm{~A}}$ receptor at different stages of virus internalization. (A) Glial cells were transiently transfected with a $5 \mathrm{HT}_{2 \mathrm{~A}} \mathrm{R}-\mathrm{GFP}$ serotonin receptor construct, and the fusion protein was visualized by confocal microscopy. ( $B$ and C) $5 \mathrm{HT}_{2 \mathrm{~A}} \mathrm{R}-\mathrm{GFP}$-expressing cells were exposed to AlexaFluor594-labeled JCV (red) and al-
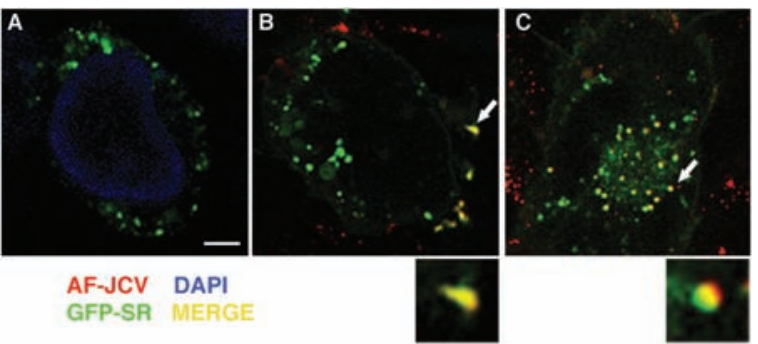
lowed to internalize for $5 \mathrm{~min}$ (B) or $30 \mathrm{~min}(\mathrm{C})$. At both time points, virus is shown to colocalize with the $5 \mathrm{HT}_{2 \mathrm{~A}}$-GFP receptor (yellow). Insets show an enlarged portion of the image identified by arrows. Scale bar, $10 \mu$.

fection. Glial cells were pre-incubated with equivalent amounts of each antibody and then challenged with JCV. None of the antibodies to dopamine receptors specifically inhibited infection of glial cells by JCV (Fig. 2A). In contrast, the antibodies to both $5 \mathrm{HT}_{2 \mathrm{~A}} \mathrm{R}$ and $5 \mathrm{HT}_{2 \mathrm{C}} \mathrm{R}$ significantly inhibited infection (Fig. 2A). These antibodies had no effect on infection if added 24 hours after infection (Fig. 2A). As a control for specificity, we pre-incubated glial cells with antibodies to $5 \mathrm{HT}_{2 \mathrm{~A}} \mathrm{R}$ or $5 \mathrm{HT}_{2 \mathrm{C}} \mathrm{R}$ and then challenged with the related virus, SV40. These antibodies had no significant effect on infection of glial cells by SV40 (Fig. 2B).

We next asked if we could rescue infection in $5 \mathrm{HT}_{2 \mathrm{~A}}$ receptor-negative cells by transient and/or stable expression of a $5 \mathrm{HT}_{2 \mathrm{~A}}$ receptor clone. HeLa cells did not express either $5 \mathrm{HT}_{2 \mathrm{~A}}$ or $5 \mathrm{HT}_{2 \mathrm{C}}$ receptors but expressed abundant levels of D1, D2, D2s, and D3 dopamine receptors (Fig. 3A). We transiently transfected HeLa cells with p5 $\mathrm{HT}_{2 \mathrm{~A}} \mathrm{R}$ or a control vector, and at 24 hours after transfection the cells were infected with JCV at an MOI of 10.0. Infection was assayed 48 hours after infection. HeLa cells transfected with the control construct (mock) remained refractory to JCV infection (Fig. 3B). In contrast, HeLa cells transfected with the $5 \mathrm{HT}_{2 \mathrm{~A}}$ receptor clone became susceptible to infection (Fig. 3B). The percentage of infected cells was low $(5 \%)$ but consistent with the low transfection efficiency of HeLa cells. We next established a HeLa cell line stably expressing the $5 \mathrm{HT}_{2 \mathrm{~A}}$ receptor by cotransfection of $\mathrm{p} 5 \mathrm{HT}_{2 \mathrm{~A}} \mathrm{R}$ with a plasmid encoding resistance to puromycin (pMSCVpuro) (Fig. 3C). HeLa-5HT ${ }_{2 \mathrm{~A}} \mathrm{R}$ cells were then challenged with JCV in the presence and absence of antibodies to
$5 \mathrm{HT}_{2 \mathrm{~A}} \mathrm{R}$. The HeLa-5HT ${ }_{2 \mathrm{~A}} \mathrm{R}$ cells were readily infected by JCV at levels comparable to infection in SVG-A glial cells (Fig. 3C). Infection of both cell types by JCV was blocked by antibody to $5 \mathrm{HT}_{2 \mathrm{~A}} \mathrm{R}$ (Fig. 3C).

Glial cells were transfected with a GFPtagged $5 \mathrm{HT}_{2 \mathrm{~A}}$ receptor clone and then incubated with Alexa-fluor 594-labeled JCV at 24 hours after transfection when GFP expression was maximal (26). Virus binding was first synchronized by incubation with the cells at $4{ }^{\circ} \mathrm{C}$ for $30 \mathrm{~min}$. The cells were then either fixed immediately or warmed to $37^{\circ} \mathrm{C}$ for $5 \mathrm{~min}$ or $30 \mathrm{~min}$ and then fixed. When the cells were allowed to internalize virus at $37^{\circ} \mathrm{C}$ for $5 \mathrm{~min}$ or $30 \mathrm{~min}$, strong colocalization between the virus and the $5 \mathrm{HT}_{2 \mathrm{~A}}$ receptors was seen (Fig. 4). The virus appeared to initially interact only with the alpha 2-6-linked sialic acid component of the JCV receptor, and then at $37^{\circ} \mathrm{C}$ interacted with the $5 \mathrm{HT}_{2 \mathrm{~A}}$ receptor. This second interaction most likely leads to efficient and rapid virus internalization. This is not unexpected, because both JCV and $5 \mathrm{HT}_{2 \mathrm{~A}}$ receptors are rapidly internalized by clathrin-dependent endocytosis after ligand binding. This is also consistent with the fact that JCV internalization is accompanied by activation of the MAP kinases ERKs1 and 2, because serotonin binding to $5 \mathrm{HT}_{2 \mathrm{~A}}$ receptors also activates ERKs 1 and $2(12,27,28)$

Compared with other polyomaviruses, JCV has a very restricted tropism, infecting 
oligodendrocytes, astrocytes, kidney epithelial cells, and, to a limited extent, B lymphocytes. In vitro, the virus can only be efficiently propagated in primary human fetal glial cells or in human fetal glial cell lines such as POJ and SVG (29-31). This restricted tropism is due to the presence or absence of cell-type-specific transcription and replication factors and to the presence of specific virus receptors. HeLa cells are completely refractory to infection by JCV but will support early viral gene expression when transfected with JCV DNA. HeLa cells express the JCV receptor-type sialic acid ( $\alpha$ 2-6 SA) and bind virus as well as permissive glial cells, suggesting that sialic acid is not sufficient for mediating virus infection (32). Our ability to rescue JCV infection in receptor-negative HeLa cells by transiently or stably introducing the $5 \mathrm{HT}_{2 \mathrm{~A}}$ receptor demonstrates that $5 \mathrm{HT}_{2 \mathrm{~A}} \mathrm{R}$ is a functional entry receptor for JCV. The breadth of other serotonergic receptors that might also function as JCV receptors has not been thoroughly investigated, but preliminary data have ruled out the 5HT1, 5HT3, and 5HT7 families.

Neurons express abundant levels of serotonin receptors but are generally refractory to infection by JCV. However, neurons do not express the receptor-type sialic acid for $\mathrm{JCV}$, which indicates that infection of cells requires both components of the JCV receptor (9). Oligodendrocytes, astrocytes, B lymphocytes, and kidney epithelial cells all express both the alpha 2-6-linked sialic acid component of the JCV receptor and $5 \mathrm{HT}_{2 \mathrm{~A}}$ receptors $(9,33-39)$.

5HT2-family receptors are highly expressed on brain microvasculature, on astrocytes at the blood-brain barrier, and in brain regions lacking the blood-brain barrier, such as the area postrema and the choroid plexus. This raises the possibility that JCV may directly traffic to the CNS via the blood under viremic conditions, as occurs during severe and prolonged immunosuppression.

Finally, serotonin receptor agonists and antagonists are widely used to treat a variety of neurological and psychiatric disorders. Drugs that have been developed to treat PML have all been hampered by poor bioavailability in the CNS, a problem not inherent to serotonergic inhibitors. Prophylactic treatment of HIV-infected patients with serotonergic antagonists may prevent the spread of JCV to the CNS and the development of PML. Aggressive therapeutic treatment of patients with PML may reduce viral spread within the $\mathrm{CNS}$ and prevent additional episodes of demyelination.

\section{References and Notes}

1. R. C. Holman, T. J. Torok, E. D. Belay, R. S. Janssen, L. B. Schonberger, Neuroepidemiology 17, 303 (1998). 2. D. L. Walker, R. J. Frisque, in The Papovaviridae,
N. P. Salzman, ed. (Plenum, New York and London, 1986), pp. 327-377.

3. S. Bofill-Mas, S. Pina, R. Girones, Appl. Environ. Microbiol. 66, 238 (2000).

4. J. R. Berger, E. O. Major, Semin. Neurol. 19, 193 (1999).

5. S. A. Houff et al., N. Engl. J. Med. 318, 301 (1988).

6. M. G. C. Monaco, W. J. Atwood, M. Gravell, C. S. Tornatore, E. O. Major, J. Virol. 70, 7004 (1996).

7. M. C. Monaco, P. N. Jensen, J. Hou, L. C. Durham, E. O. Major, J. Virol. 72, 9918 (1998).

8. C. K. Liu, G. Wei, W. J. Atwood, J. Virol. 72, 4643 (1998)

9. S. Eash et al., Am. J. Pathol. 164, 419 (2004).

10. B. J. Chen, W. J. Atwood, Virology 300, 282 (2002).

11. M. T. Pho, A. Ashok, W. J. Atwood, J. Virol. 74, 2288 (2000).

12. W. Querbes, A. Benmerah, D. Tosoni, P. P. Di Fiore, W. J. Atwood, J. Virol. 78, 250 (2004).

13. L. Pelkmans, J. Kartenbeck, A. Helenius, Nature Cell Biol. 3, 473 (2001)

14. L. C. Norkin, Immunol. Rev. 168, 13 (1999).

15. L. C. Norkin, H. A. Anderson, S. A. Wolfrom, A. Oppenheim, J. Virol. 76, 5156 (2002).

16. S. Baum et al., J. Neurovirol. 9, 32 (2003).

17. A. Newman-Tancredi et al., J. Pharmacol. Exp. Ther. 303, 815 (2002)

18. M. Velasco, A. Luchsinger, Am. J. Ther. 5, 37 (1998).

19. K. Herrick-Davis, E. Grinde, M. Teitler, J. Pharmacol. Exp. Ther. 295, 226 (2000).

20. P. K. Gillman, J. Psychopharmacol. 13, 100 (1999).

21. F. G. Boess, I. L. Martin, Neuropharmacology 33, 275 (1994).

22. M. S. Choudhary, S. Craigo, B. L. Roth, Mol. Pharmacol. 42, 627 (1992)

23. M. Dudley, A. Ogden, A. Carr, T. Nieduzak, J. Kehne, Soc. Neurosci. Abstr. 16, 1037 (1990).

24. J. L. Herndon, A. Ismaiel, S. P. Ingher, M. Teitler, R. A. Glennon, J. Med. Chem. 35, 4903 (1992).

25. K. Kristiansen, S. G. Dahl, Eur. J. Pharmacol. 306, 195 (1996).

26. A. Bhatnagar et al., J. Biol. Chem. 276, 8269 (2001).

27. D. Hoyer et al., Pharmacol. Rev. 46, 157 (1994).

28. A. Bhatnagar, D. J. Sheffler, W. K. Kroeze, B. Compton-Toth, B. L. Roth, J. Biol. Chem. 279, 34614 (2004)
29. C. Mandl, D. L. Walker, R. J. Frisque, J. Virol. 61, 755 (1987).

30. B. Padgett, G. ZuRhein, D. Walker, R. Echroade, B. Dessel, Lancet I, 1257 (1971).

31. E. O. Major et al., Proc. Natl. Acad. Sci. U.S.A. 82, 1257 (1985).

32. G. Wei, C. K. Liu, W. J. Atwood, J. Neurovirol. 6, 127 (2000).

33. A. Merzak, S. Koochekpour, M. P. Fillion, G. Fillion, G. J. Pilkington, Brain Res. Mol. Brain Res. 41, 1 (1996).

34. Z. Cohen et al., J. Cereb. Blood Flow Metab. 19, 908 (1999).

35. M. I. Fonseca, Y. G. Ni, D. D. Dunning, R. Miledi, Brain Res. Mol. Brain Res. 89, 11 (2001).

36. S. Belachew et al., Neuroreport 9, 973 (1998)

37. J. A. Gray et al., Mol. Pharmacol. 60, 1020 (2001).

38. D. W. Bonhaus et al., Br. J. Pharmacol. 115, 622 (1995).

39. M. Chang, L. Zhang, J. P. Tam, E. Sanders-Bush, J. Biol. Chem. 275, 7021 (2000)

40. We would like to thank all members of the Atwood laboratory for critical discussion during the course of this work. We thank J. Sedivy for critical discussions during the preparation of the manuscript. We also thank L. Brossay for the pMSCV plasmid, R. Creton for critical help with confocal microscopy, and A. Robinson, A. Bozek, and L. St. Pierre for administrative assistance. Work in our laboratory was supported by a grant from the National Cancer Institute, R01 CA71878, and by a grant from the National Institute of Neurological Disorders and Stroke, R01 NS43097. W.Q. is supported by a Graduate Assistantship in Areas of National Need training grant from the Department of Education, P200A030100. Work in the Roth lab was supported by RO1MH57635, RO1MH61887, and the National Institute of Mental Health Psychoactive Drug Screening Program to B.L.R.

\section{Supporting Online Material}

www.sciencemag.org/cgi/content/full/306/5700/1380/ DC

Materials and Methods

2 August 2004; accepted 21 September 2004

\title{
Fat Mobilization in Adipose Tissue Is Promoted by Adipose Triglyceride Lipase
}

\author{
Robert Zimmermann, ${ }^{1 *}$ Juliane G. Strauss, ${ }^{1 *}$ \\ Guenter Haemmerle, ${ }^{1}$ Gabriele Schoiswohl, ${ }^{1}$ \\ Ruth Birner-Gruenberger, ${ }^{3}$ Monika Riederer, ${ }^{1}$ \\ Achim Lass, ${ }^{1}$ Georg Neuberger, ${ }^{2}$ Frank Eisenhaber, ${ }^{2}$ \\ Albin Hermetter, ${ }^{3}$ Rudolf Zechner ${ }^{1} \dagger$
}

\begin{abstract}
Mobilization of fatty acids from triglyceride stores in adipose tissue requires lipolytic enzymes. Dysfunctional lipolysis affects energy homeostasis and may contribute to the pathogenesis of obesity and insulin resistance. Until now, hormone-sensitive lipase (HSL) was the only enzyme known to hydrolyze triglycerides in mammalian adipose tissue. Here, we report that a second enzyme, adipose triglyceride lipase (ATGL), catalyzes the initial step in triglyceride hydrolysis. It is interesting that ATGL contains a "patatin domain" common to plant acyl-hydrolases. ATGL is highly expressed in adipose tissue of mice and humans. It exhibits high substrate specificity for triacylglycerol and is associated with lipid droplets. Inhibition of ATGL markedly decreases total adipose acyl-hydrolase activity. Thus, ATGL and HSL coordinately catabolize stored triglycerides in adipose tissue of mammals.
\end{abstract}

Animals, seed plants, and fungi commonly store excessive amounts of energy substrates in the form of intracellular triglyc- eride (TG) deposits. In mammals, TGs are stored in adipose tissue, where they provide the primary source of energy during peri- 


\section{Science}

\section{The Human Polyomavirus, JCV, Uses Serotonin Receptors to Infect Cells}

Gwendolyn F. Elphick, William Querbes, Joslynn A. Jordan, Gretchen V. Gee, Sylvia Eash, Kate Manley, Aisling Dugan, Megan Stanifer, Anushree Bhatnagar, Wesley K. Kroeze, Bryan L. Roth and Walter J. Atwood

Science 306 (5700), 1380-1383

DOI: 10.1126/science.1103492

ARTICLE TOOLS
http://science.sciencemag.org/content/306/5700/1380
$\begin{aligned} & \text { SUPPLEMENTARY } \\ & \text { MATERIALS }\end{aligned}$
$\begin{aligned} & \text { http://science.sciencemag.org/content/suppl/2004/11/17/306.5700.1380.DC1 } \\ & \text { http://science.sciencemag.org/content/sci/309/5733/381.2.full } \\ & \text { http://stke.sciencemag.org/content/sigtrans/2004/260/tw425.abstract }\end{aligned}$
$\begin{aligned} & \text { RELATED } \\ & \text { CONTENT } \\ & \text { This article cites } 38 \text { articles, } 17 \text { of which you can access for free } \\ & \text { http://science.sciencemag.org/content/306/5700/1380\#BIBL }\end{aligned}$
Pttp://www.sciencemag.org/help/reprints-and-permissions

Use of this article is subject to the Terms of Service

Science (print ISSN 0036-8075; online ISSN 1095-9203) is published by the American Association for the Advancement of Science, 1200 New York Avenue NW, Washington, DC 20005. 2017 (C) The Authors, some rights reserved; exclusive licensee American Association for the Advancement of Science. No claim to original U.S. Government Works. The title Science is a registered trademark of AAAS. 